\title{
Knowledge of Diabetic Patients in Al-Kut City According to Revised Michigan Diabetes Knowledge Test
}

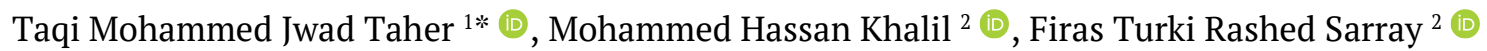

\author{
${ }^{1}$ FABHS-CM, Family and Community Medicine Department, College of Medicine, Wasit University, Wasit, IRAQ \\ ${ }^{2} \mathrm{Al}$-Zahraa Teaching Hospital, Wasit Health Directorate, Ministry of Health, Wasit, IRAQ \\ *Corresponding Author: ttahir@uowasit.edu.iq
}

Citation: Taher TMJ, Khalil MH, Sarray FTR. Knowledge of Diabetic Patients in Al-Kut City According to Revised Michigan Diabetes Knowledge Test. ELECTR J MED DENT STUD. 2022;12(1):em0093. https://doi.org/10.29333/ejmds/11561

\section{ARTICLE INFO}

Received: 25 Sep. 2021

Accepted: 5 Dec. 2021

\begin{abstract}
Background: Diabetes Mellites is a public health concern in Iraq. It was known that when patients have better knowledge about their illnesses, it is leading to more treatment adherence and finally fewer complications so the current study aims to assess the diabetic patient's knowledge about their disease using Michigan Diabetes Knowledge Scale.
\end{abstract}

Methods: This is a cross-sectional study performed among 384 randomly selected patients attending the diabetic center at Al-Zahraa Teaching Hospital in Wasit. All patients were formally consented to answer an Arabic revised Michigan Diabetes Knowledge Test.

Results: The mean age and slandered deviation for patients was $(43.85 \pm 17.25)$ years old. The female patients represented $58.6 \%$, about two-thirds of cases (66.1\%) were married, $40.1 \%$ with high educational level, about three quarters didn't do any exercise (76.3\%), only $17.4 \%$ of them are smokers. The majority $(78.91 \%)$ of patients had a good knowledge score and $21.09 \%$ had low knowledge scores. The major source of knowledge mentioned by patients $(75.52 \%)$ was from hospitals and physicians. The knowledge score was significantly associated with the type of medication and smoking status ( $\mathrm{p}$-value $<0.001$ and 0.019 ), respectively.

Conclusions: The good knowledge score was found in the majority of patients visiting the diabetic center in ALZahraa Teaching Hospital. Most of the patients were adherence to their treatment which reflects the knowledge's effect on their behaviors.

Keywords: diabetes mellitus, knowledge, Michigan diabetes knowledge test, chronic disease, Iraq

\section{INTRODUCTION}

As Diabetes Mellitus (DM) at this time affects more than 366 million humans around the world, it is appeared to be the most important non-communicable disease confronting the health sector in the current century [1]. The epidemiological reports about the disease had shown that increasing the international prevalence of DM among adult people from $4.7 \%$ in 1980 to be around $8.5 \%$ in 2014 [2]. This increase in the prevalence of DM was more obvious in middle- and lowincome countries especially in Iraq where the number of adult diabetic cases was reached 1,447,646 in 2017 [2,3]. So, accordingly, it is highly suspected that the prevalence of DM to be multiplied by two within the next 10 years [1].

Diabetes can be complicated by severe and lethal problems like renal failure, heart failure, stroke, limb amputation, and even blindness. The World Health Organization (WHO) ranked the DM as the seventh cause of death universally in 2016 when the number of deaths exceeds 1.6 million [2]. There are a lot of preventive measures that can be conducted by patients to fight against early death from diabetes-like keeping healthy dietary habits, commitment to a suitable physical activity program, compliance with prescribed medication, and regular examination for early detection of any potential complications [2]. It is of great help for diabetic patients to be well educated about the relevant issues related to their disease especially self-care knowledge which can affect their self-care practice and finally prevent deaths and complications [4].

To reach optimum patient care, we need to emerge patients in a required and suitable educational program that meets their needs. Thus, we have to assess the current knowledge status and specify the knowledge deficit among patients to be covered in future educational programs. The Michigan Diabetes Knowledge Test (MDKT) was used for assessment knowledge status among DM patients because it was confirmed to be appropriate for adults, easy to understand and answered, in addition to proven reliability scores reaching 0.7 $[5,6]$. This test was broadly used in different countries besides the Michigan populations like in Saudi Arabia, the United Arab 
Emirates, and Nigeria [7-9]. Hence, we were interested in applying it for Al-Kut city diabetic patients to assess the knowledge regarding their disease, complications, and the ways of controlling blood sugar to improve control and decrease death rates. Knowledge had an effective role in decreasing complications, good controlling the disease, and finally decreasing the death rate.

\section{PATIENTS AND METHODS}

An analytic cross-sectional study, conducted between June and September 2019. Using the sample size equation for crosssectional studies to estimate the acquired sample size, 384 adult patients were randomly selected from the patients' list. All patients included in this study, aged 18 years old and above who were registered in the diabetic center at Al-Zahraa Teaching Hospital- the only center in Al-Kut city for diabetic patients- to get treatment and advice about their disease by specialist physicians. All diabetic patients fitted to the inclusion criteria of the study were consented to participate after explaining the objectives of the study.

After taking approval from the Ethical and Scientific Committee belonging to the College of Medicine in Wasit University, a modified, Arabic translated revised (MDKT) [10] questionnaire was prepared to gather the data including 20 questions about the knowledge items answered by one of the following choices (false, true, or don't know). Demographic data (age, sex, occupation, educational level, marital status, smoking, and exercise) in addition to medical history (the type of medication and compliance with medication) were also included.

Using the SPSS program version 23 for data entry and analysis. The age was presented as a mean and standard deviation; other data were presented in frequency tables. Chisquare and t-test were used for association at a significant level of 0.05. All questions regarding DM knowledge that were answered correctly were coded by number 1 , while zero was given for incorrect and don't know answers. The mean knowledge score for each patient was calculated and classified into good and low knowledge levels according to the cutoff point 50 from 100 .

\section{RESULTS}

According to the sociodemographic features of 384 diabetic patients contributed to the study, the mean age \pm standard deviation of the patients was $(43.85 \pm 17.25)$ years and the age range (18-82) years old.

Female patients represented $58.6 \%$, about two-thirds of cases $(66.1 \%)$ were married, $40.1 \%$ with high educational level, about three quarters did not do any exercise (76.3\%), only 17.4\% of them are smokers as shown in Table 1.

Less than half (40.4\%) of the diabetic patients had only oral tablets and only (19.5\%) had no medication, most of the cases (90.6\%) mentioned that they were compliant with treatment (Table 2).
Table 1. The frequency distribution of diabetic patients' characteristics in Al-Kut city, 2019

\begin{tabular}{|c|c|c|c|}
\hline Variables & & Frequency & Percentage \\
\hline \multirow{2}{*}{ Gender } & Male & 159 & 41.4 \\
\hline & Female & 225 & 58.6 \\
\hline \multirow{3}{*}{$\begin{array}{c}\text { Marital } \\
\text { status }\end{array}$} & Single & 103 & 26.8 \\
\hline & Married & 254 & 66.1 \\
\hline & Divorced or Widower & 27 & 7.0 \\
\hline \multirow{3}{*}{$\begin{array}{c}\text { Educational } \\
\text { level }\end{array}$} & Primary and below & 116 & 30.2 \\
\hline & Intermediate to College & 114 & 29.7 \\
\hline & College and higher & 154 & 40.1 \\
\hline \multirow{2}{*}{ Exercise } & Yes & 91 & 23.7 \\
\hline & No & 293 & 76.3 \\
\hline \multirow{2}{*}{ Smoking } & Yes & 67 & 17.4 \\
\hline & No & 317 & 82.6 \\
\hline
\end{tabular}

Table 2. Frequency distribution table of the medication

\begin{tabular}{cccc}
\hline Variables & & Frequency & Percentage \\
\hline \multirow{3}{*}{$\begin{array}{c}\text { Type of } \\
\text { medication }\end{array}$} & Oral tablets & 155 & 40.4 \\
\cline { 2 - 4 } & Oral tablets and insulin & 107 & 27.9 \\
\cline { 2 - 4 } & No medication & 77 & 12.2 \\
\cline { 2 - 4 } & Total & 384 & 19.5 \\
\hline \multirow{2}{*}{$\begin{array}{c}\text { Compliance } \\
\text { to treatment }\end{array}$} & Yes & 280 & 100.0 \\
\cline { 2 - 4 } & No & 29 & 90.6 \\
\cline { 2 - 4 } & Total & 309 & 100.4 \\
\hline
\end{tabular}

Respectively, (96.6\%), (94.3\%), and (90.9\%) were the highest percentage of correct answers of the patients which belonging to questions: "Having regular check-ups with your doctor can help spot the early signs of diabetes complications", "Eating foods lower in fat decreases your risk for heart disease", and "Exercising regularly can help reduce high blood pressure".

While (4.4\%), (9.9\%), and (26\%) of the diabetic cases had the lowest right answers for these questions respectively: "Attending your diabetes appointments stops you getting diabetes complications", "Wearing shoes a size bigger than usual helps prevent foot ulcers", "Urine testing and blood testing are both equally as good for testing the level of blood glucose". Among 154 patients using insulin $85.1 \%$ had the right answer about this question "High blood glucose levels may be caused by too much insulin", and $89.6 \%$ about this question "If you take your morning insulin but skip breakfast your blood glucose level will usually decrease" as shown in Table 3.

Figure 1 and Figure 2 show the mean and standard deviation for the knowledge score of the diabetic cases $(0.56 \pm 0.14)$, with $78.91 \%$ having good knowledge and $21.09 \%$ having low knowledge scores.

The mean age of good knowledge patients was (43.95 \pm 16.679$)$, while the mean age for low knowledge score patients $(43.48 \pm 19.345)$ with a non-significant $\mathrm{p}$-value (t-test) of 0.828 . 
Table 3. Frequency distribution of correct answers to knowledge questions in Al-Kut city, 2019

\begin{tabular}{|c|c|c|}
\hline Questions about diabetic knowledge & Number & $\%$ \\
\hline The diabetes diet is a healthy diet for most people. & 253 & 65.9 \\
\hline Glycosylated hemoglobin (HbA1c) is a test that measures your average blood glucose level in the past week. & 170 & 44.3 \\
\hline A kilo of chicken has more carbohydrates in it than a kilo of potatoes. & 191 & 49.7 \\
\hline Orange juice has more fat in it than low-fat milk. & 253 & 65.9 \\
\hline Urine testing and blood testing are both equally as good for testing the level of blood glucose. & 100 & 26.0 \\
\hline Unsweetened fruit juice raises blood glucose levels. & 112 & 29.2 \\
\hline A can of a soft drink can be used for treating low blood glucose levels. & 233 & 60.7 \\
\hline Using olive oil in cooking can help prevent raised cholesterol in the blood. & 316 & 82.3 \\
\hline Exercising regularly can help reduce high blood pressure. & 349 & 90.9 \\
\hline For a person in good control, exercising does not affect blood sugar levels. & 194 & 50.5 \\
\hline Infection is likely to cause an increase in blood sugar levels. & 190 & 49.5 \\
\hline Wearing shoes a size bigger than usual helps prevent foot ulcers. & 38 & 9.9 \\
\hline Eating foods lower in fat decreases your risk for heart disease. & 362 & 94.3 \\
\hline Numbness and tingling may be symptoms of nerve disease. & 299 & 77.9 \\
\hline Lung problems are usually associated with having diabetes. & 147 & 38.3 \\
\hline When you are sick with the flu you should test for glucose more often. & 209 & 54.4 \\
\hline Having regular check-ups with your doctor can help spot the early signs of diabetes complications. & 371 & 96.6 \\
\hline Attending your diabetes appointments stops you from getting diabetes complications. & 17 & 4.4 \\
\hline \multicolumn{3}{|l|}{$\begin{array}{ll}\text { Among } 154 \text { patients using insulin } \\
\end{array}$} \\
\hline High blood glucose levels may be caused by too much insulin. & 131 & 85.1 \\
\hline If you take your morning insulin but skip breakfast your blood glucose level will usually decrease. & 138 & 89.6 \\
\hline
\end{tabular}

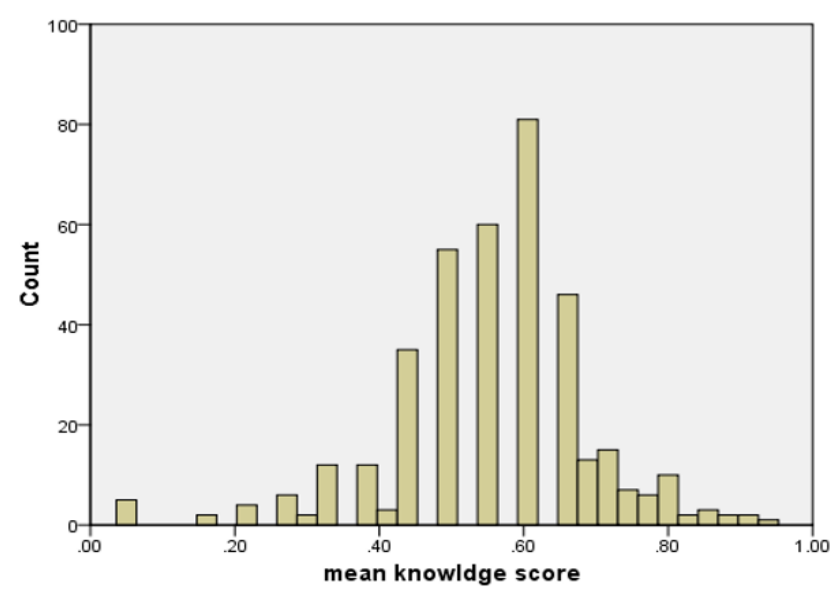

Figure 1. The mean knowledge score

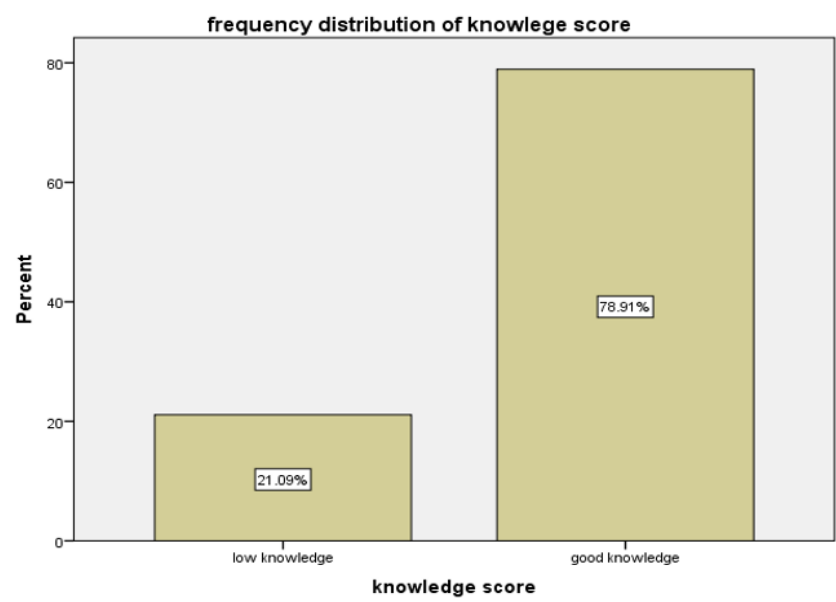

Figure 2. Frequency distribution of knowledge score

Table 4 showed significant differences between patients' knowledge regarding their smoking status and the type of medication used. While it was not significant with other studied variables.
Table 4. The frequency distribution of the patients' characteristics according to knowledge score

\begin{tabular}{|c|c|c|c|c|}
\hline & \multirow{2}{*}{ Variables } & \multicolumn{2}{|c|}{$\begin{array}{c}\text { Knowledge score } \\
\text { number (\%) }\end{array}$} & \multirow{2}{*}{$\begin{array}{l}\text { Chi- } \\
\text { square } \\
\text { p-value }\end{array}$} \\
\hline & & $\begin{array}{c}\text { Low } \\
\text { knowledge }\end{array}$ & $\begin{array}{c}\text { Good } \\
\text { knowledge }\end{array}$ & \\
\hline \multirow{2}{*}{ Gender } & Male & $27(17.0)$ & $132(83)$ & 0.097 \\
\hline & Female & $54(24)$ & 171(76) & \\
\hline \multirow{5}{*}{ Job } & $\begin{array}{c}\text { Governmental } \\
\text { employee }\end{array}$ & $18(24)$ & $57(76)$ & 0.193 \\
\hline & Retired & $2(6.7)$ & 28(93.3) & \\
\hline & Self-employee & $12(16.7)$ & $60(83.3)$ & \\
\hline & Unemployed & $30(22.6)$ & $103(77.4)$ & \\
\hline & Student & $19(25.7)$ & $55(74.3)$ & \\
\hline \multirow{3}{*}{$\begin{array}{l}\text { Marital } \\
\text { status }\end{array}$} & Single & $27(26.2)$ & $76(73.8)$ & 0.304 \\
\hline & Married & $48(18.9)$ & $206(81.1)$ & \\
\hline & $\begin{array}{l}\text { Divorced or } \\
\text { Widower }\end{array}$ & $6(22.2)$ & $21(77.8)$ & \\
\hline \multirow{3}{*}{$\begin{array}{c}\text { Educational } \\
\text { level }\end{array}$} & Primary and below & $25(21.6)$ & 91(78.4) & 0.687 \\
\hline & $\begin{array}{c}\text { Intermediate to } \\
\text { College }\end{array}$ & $21(18.4)$ & $93(81.6)$ & \\
\hline & College and higher & $35(22.7)$ & $119(77.3)$ & \\
\hline \multirow{2}{*}{ Exercise } & Yes & $15(16.5)$ & $76(83.5)$ & 0.217 \\
\hline & No & $66(22.5)$ & $227(77.5)$ & \\
\hline \multirow{2}{*}{ Smoking } & Yes & $7(10.4)$ & $60(89.6)$ & 0.019 \\
\hline & No & $74(23.3)$ & $243(76.7)$ & \\
\hline \multirow{4}{*}{$\begin{array}{c}\text { Type of } \\
\text { medication }\end{array}$} & Oral tablets & $36(23.2)$ & $119(76.8)$ & $<0.001$ \\
\hline & Insulin & $12(11.2)$ & $95(88.8)$ & \\
\hline & $\begin{array}{l}\text { Oral tablets and } \\
\text { Insulin }\end{array}$ & $3(6.4)$ & $44(93.6)$ & \\
\hline & None & $30(40)$ & $45(60)$ & \\
\hline
\end{tabular}

Figure 3 shows the percentage of knowledge's source for the participant patients, $75.5 \%$ of the cases provided their DM education from physician and hospital while only $9.9 \%$ provided from the media and the Internet. 


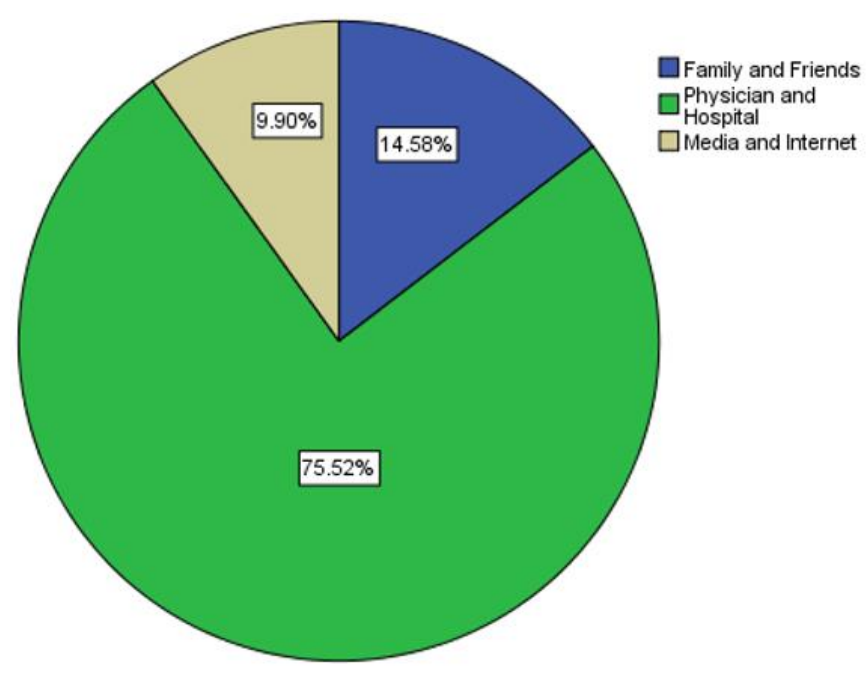

Figure 3. Percentages of knowledge's sources

\section{DISCUSSION}

Patients living with chronic diseases like DM need to be well educated about their condition so they can deal perfectly with the medication and self-care practice to prevent further complications [11, 12]. The required knowledge should cover different aspects that have an important effect on disease control such as healthy eating habits, types of physical activities, routine investigations, and danger signs that need urgent management [13, 14]. Lots of studies performed in different countries like Tunisia, Egypt, Saudi Arabia, Kuwait, China, UK, the Philippines, and India found poor knowledge levels among diabetic patients [15-22]. It is of no value to compare these results with the current study because they were applied to different ethnic or age groups using different assessment tools. In general, the highest percentage of the patients in this study showed a good knowledge score while less than one quarter had low knowledge. The high level of knowledge among patients regarding diabetes complications and diet may be due to their routine hospital visits and experienced this information mainly from physicians (75.5\%). Even men appeared to be more knowledgeable regarding diabetes rather than women, but this result was insignificant and is conflicting with other studies in India, USA, and Pakistan [22-24].

This study found no significant association between the knowledge score and the educational level of the patients which was conflicting with the results of studies from the United Arab Emirates (UAE) and Bangladesh [8, 25]. Also, there is no association between knowledge and marital status which was inconsistent with Saudi Arabia and USA studies [7, 26].

In our study, retired people had more knowledge than other jobs and the students had a lower percentage, maybe due to the age and the retired people had time and interest to concentrate on their health. Even, this also was an insignificant association. There is no significant relationship between knowledge and exercise, although approximately three-quarters of the patients who did exercise had good knowledge and only three-quarters of patients who did not do exercise also had good knowledge.
Smoker's diabetic patients had significantly higher knowledge about DM than non-smokers which may be attributed to the fact of being smoking as a recognized risk factor for complications [27] which is in turn made smoker patients attain more knowledge regarding the disease to prevent future complications. Although, another study conducted in a Japanese community found that non-smokers have a higher percentage of good knowledge than formal and current smokers [28]. There is a significant relationship between types of medications and knowledge, the highest knowledge was among patients who took both insulin and oral tablets together and the lowest knowledge was among patients who didn't take any medication, perhaps because those with medication are concerned more about their disease and try to get more control. The majority of those patients with medications had good adherence to management, which was found to be significantly associated with disease knowledge [29]. Probably this point is one of the reasons that affect the results of our study.

The defined limitations in this study include the recall bias when answering the questions and the selection bias because patients who are under regular follow-up in the teaching hospital diabetes center who expected to get improved care and support than others visiting the primary health care centers or visiting private clinics.

\section{CONCLUSIONS AND RECOMMENDATIONS}

Diabetic patients visiting the diabetic center in Al-Zahraa Teaching Hospital had a high percentage of good knowledge regarding their disease issues. The smoking status and the type of medication were significantly associated with their knowledge status. special attention should be paid to the elderly and illiterate patients. Also, patients on insulin should receive special attention as knowledge of DM management for them is key. For the future, it is important to take into consideration variability in places and increasing the sample size to assess knowledge and to correlate with the best practice among patients regarding their disease.

Author contributions: All co-authors have involved in all stages of this study while preparing the final version. They all agree with the results and conclusions.

Funding: No external funding is received for this article.

Declaration of interest: The authors declare that they have no competing interests.

Ethics approval and consent to participate: Not applicable.

Availability of data and materials: All data generated or analyzed during this study are available for sharing when appropriate request is directed to corresponding author.

\section{REFERENCES}

1. Karaoui LR, Deeb ME, Nasser L, Hallit S. Knowledge and practice of patients with diabetes mellitus in Lebanon: a cross-sectional study. BMC Public Health. 2018;18(1): 525. doi: 10.1186/s12889-018-5416-7 PMid:29678148 PMCid: PMC5910622. 
2. World Health Organization. Diabetes Mellitus. Available at: https://www.who.int/news-room/fact-sheets/detail/ diabetes

3. International Diabetic Federation. IDF Diabets Atlas. Available at: https://www.worlddiabetesfoundation.org/ sites/default/files/Atlas-8e-regional-fact-sheet-18-99MENA\%20\%281\%29.pdf

4. Khurshid TK, Othman SM. Knowledge and practice about diabetes among adult diabetic patients in Erbil, Iraq. Zanco J Med Sci. 2014;18(1):659-66. doi: 10.15218/zjms.2014.0011.

5. Fitzgerald JT, Funnell MM, Hess GE, et al. The reliability and validity of a brief diabetes knowledge test. Diabetes Care. 1998;21(5):706-10. doi: 10.2337/diacare.21.5.706. PMid:9589228

6. Stallwood L. Relationship between caregiver knowledge and socioeconomic factors on glycemic outcomes of young children with diabetes. J Spec Pediatr Nurs. 2006;11(3):158-65. doi: 10.1111/j.17446155.2006.00062.x PMid:6774526.

7. Al-Aboudi IS, Hassali MA, Shafie AA. Knowledge, attitudes, and quality of life of type 2 diabetes patients in Riyadh, Saudi Arabia. J Pharm Bioallied Sci. 2016;8(3):195-202. doi: 10.4103/0975-7406.171683 PMid:27413347 PMCid: PMC4929958.

8. Al-Maskari F, El-Sadig M, Al-Kaabi JM, Afandi B, Nagelkerke N, Yeatts KB. Knowledge, attitude and practices of diabetic patients in the United Arab Emirates. PLoS One. 2013;8(1):e52857. doi: 10.1371/journal.pone. 0052857 PMid:23341913 PMCid:PMC3544806

9. Adejoh SO. Diabetes knowledge, health belief, and diabetes management among the Igala, Nigeria. SAGE Open. 2004; 4(2):215824401453996. doi: 10.1177/2158244014539966

10. The Michigan Diabetes Research and Training Center (MDRTC). Available at: http://www.med.umich.edu/mdrtc/ profs/survey.html

11. Standard Treatment Guidelines for Primary Hospitals. Ethiopia. Available at: http://digicollection.org/hss/en/m/ abstract/Js17820en/

12. Standards of Medical Care in Diabetes-2013. Diabetes Care. 2012;36(Supplement 1):S11-S66. doi: 10.2337/dc13-s011 PMid:23264422 PMCid:PMC3537269.

13. Gautam A, Bhatta DN, Aryal UR. Diabetes-related health knowledge, attitude, and practice among diabetic patients in Nepal. BMC Endocr Disord. 2015;15:25. doi: 10.1186/s12902-015-0021-6 PMid:26045031 PMCid: PMC4456997.

14. Saleh F, Mumu SJ, Ara F, Begum HA, Ali L. Knowledge and self-care practices regarding diabetes among newly diagnosed type 2 diabetics in Bangladesh: a cross-sectional study. BMC Public Health. 2012;12:1112. doi: 10.1186/1471-2458-12-1112 PMid:23267675 PMCid: PMC3552981.

15. Ben Abdelaziz A, Thabet H, Soltane I, et al. Knowledge of patients with type 2 diabetes about their condition in Sousse, Tunisia. East Mediterr Health J. 2007;13(3):505-14. PMid:17687822.
16. Kamel NM, Badawy YA, el-Zeiny NA, Merdan IA. Sociodemographic determinants of management behavior of diabetic patients. Part 2. Diabetics' knowledge of the disease and their management behavior. East Mediterr Health J. 1999;5(5):974-83. doi: 10.26719/1999.5.5.974 PMid:10983538.

17. Khan LA, Khan SA. Level of knowledge and self-care in diabetics in a community hospital in Najran. Ann Saudi Med. 2000;20(3-4):300-1. doi: 10.5144/02564947.2000.300 PMid:17322686.

18. Al-Adsani AM, Moussa MA, Al-Jasem LI, et al. The level and determinants of diabetes knowledge in Kuwaiti adults with type 2 diabetes. Diabetes Metab. 2009;35(2):121-8. doi: 10.1016/j.diabet.2008.09.005 PMid:19250850.

19. He X, Wharrad HJ. Diabetes knowledge and glycemic control among Chinese people with type 2 diabetes. Int Nurs Rev. 2007;54(3):280-7. doi: 10.1111/j.14667657.2007.00570.x PMid:17685912.

20. Speight J, Bradley C. The ADKnowl: identifying knowledge deficits in diabetes care. Diabet Med. 2001;18 (8):626-33. doi: 10.1046/j.1464-5491.2001.00537.x PMid:11553199.

21. Ardeňa GJRA, Paz-Pacheco E, Jimeno CA, et al. Knowledge, attitudes and practices of persons with type 2 diabetes in a rural community: phase I of the community-based diabetes self-management education (DSME) program in San Juan, Batangas, Philippines. Diabetes Res Clin Pract. 2010;90(2):160-6. doi: 10.1016/j.diabres.2010.08.003 PMid: 20828851.

22. Murata GH, Shah JH, Adam KD, et al. Factors affecting diabetes knowledge in type 2 diabetic veterans. Diabetologia. 2003;46:1170-8. doi: 10.1007/s00125-0031161-1 PMid:12856126.

23. Rhee MK, Cook CB, El-Kebbi I, et al. Barriers to diabetes education in urban patients: perceptions, patterns, and associated factors. Diabetes Educ. 2005;31(3):410-7. doi: 10.1177/0145721705277022 PMid:15919641.

24. Hawthorne K, Tomlinson S. Pakistani Moslems with type 2 diabetes mellitus: effect of sex, literacy skills, known diabetic complications and place of care on diabetic knowledge, reported self-monitoring management and glycaemic control. Diabet Med. 1999;16(7):591-7. doi: 10.1046/j.1464-5491.1999.00102.x PMid:10445836.

25. Islam SMS, Niessen LW, Seissler J, et al. Diabetes knowledge and glycemic control among patients with type 2 diabetes in Bangladesh. Springer Plus. 2017;4(1):1-4. doi: 10.1186/s40064-015-1103-7 PMid:26101736 PMCid: PMC4474969.

26. Persell SD, Keating NL, Landrum MB, et al. Relationship of diabetes-specific knowledge to self-management activities, ambulatory preventive care, and metabolic outcomes. Prev Med. 2004;39:746-52. doi: 10.1016/j.ypmed.2004.02.045 PMid:15351541.

27. Chang SA. Smoking and type 2 diabetes mellitus. Diabetes Metab J. 2012;36(6):399-403. doi: 10.4093/dmj.2012.36. 6.399 PMid:23275932 PMCid:PMC3530709.

28. Oba S, Yamamoto M, Horikawa Y, et al. Knowledge of diabetes and its determinants: a cross-sectional study among adults in a Japanese community. BMJ Open. 2019;9: e024556. doi: 10.1136/bmjopen-2018-024556 PMid:31152029 PMCid:PMC6549608. 
29. Nazir SU, Hassali MA, Saleem F, Bashir S, Aljadhey H. Association between diabetes-related knowledge and medication adherence: results from cross-sectional analysis. Altern Ther Health Med. 2016;22(6):8-13. PMid:27866175. 